\title{
The effect of vasectomy on pituitary-gonadal function in men
}

\author{
V. K. Naik, A. N. Thakur, A. R. Sheth, U. M. Joshi, S. S. Rao, \\ D. S. Pardanani*, J. K. Kulsreshtha† and R. K. Handa† \\ Institute for Research in Reproduction, and \\ *Department of Surgery, G.S. Medical College, Parel, Bombay 400 012, and \\ $\dagger$ †.R. Hospital, Western Railway, Bombay, India
}

Studies on the effects of vasectomy on hormone levels and accessory reproductive organ function in man have shown that there are no significant alterations in the levels of serum LH and FSH (Wieland, Hallberg, Zorn, Klein \& Luria, 1972; Johnsonbaugh, O'Connell, Engel, Edson \& Sode, 1975; Varma, Varma, Johanson, Kowarski \& Migeon, 1975) or testosterone (Bunge, 1972; Wieland et al., 1972; Johnsonbaugh et al., 1975; Varma et al., 1975), although Smith, Tcholankian, Chowdary \& Steinberger (1976) reported a significant increase in plasma testosterone and LH levels 1 year after vasectomy. Kobrinsky, Winter, Reyes \& Faiman (1976) found an acute fall in FSH and testosterone concentrations: subsequently, FSH remained below while LH and testosterone returned to the prevasectomy level (Kobrinsky et al., 1976).

Altered prostatic (Thakur, Sheth, Rao \& Thaker, 1975) and epididymal function (Pardanani, Patil \& Powar, 1976) has been observed following vasectomy. However, Nun, Musacchio \& Epstein (1972) and Thakur et al. (1975), in a cross-sectional study, found no increase in the seminal fructose of vasectomized men.

These conflicting data may be due to variations in the time after vasectomy of the different studies, and/or whether the studies were cross-sectional or longitudinal.

In the longitudinal study reported here, we have investigated the hormonal status and accessory sex organ function in 19 healthy men, aged 35-45 years, who underwent voluntary vasectomy. The investigations were carried out on the day of vasectomy and were repeated at the end of 3 months and 1 year. Serum LH and FSH levels were measured by the double antibody radioimmunoassay

Table 1. Effect of vasectomy on serum levels of testosterone, LH and FSH and on seminal citric acid, fructose, maltase, and acid phosphatase in men

\begin{tabular}{|c|c|c|c|c|c|c|}
\hline & & month & & Afte & montl & \\
\hline & Difference* & $t \dagger$ & $P$ & Difference* & $t \uparrow$ & $\boldsymbol{P}$ \\
\hline LH (mi.u./ml) & $\begin{array}{c}+2.03 \\
(19)\end{array}$ & $1 \cdot 72$ & N.S. & $\begin{array}{c}+0.69 \\
(10)\end{array}$ & 0.34 & N.S. \\
\hline FSH (mi.u./ml) & $\begin{array}{c}-0.73 \\
(19)\end{array}$ & 0.91 & N.S. & $\begin{array}{c}+3 \cdot 03 \\
(10)\end{array}$ & $2 \cdot 18$ & N.S. \\
\hline Testosterone $(\mathrm{ng} / \mathrm{ml})$ & $\begin{array}{c}+0.634 \\
(13)\end{array}$ & 0.75 & N.S. & $\begin{array}{c}+1.82 \\
(8)\end{array}$ & 1.08 & N.S. \\
\hline Fructose (mg/ml semen) & $\begin{array}{c}+2 \cdot 84 \\
(9)\end{array}$ & $17 \cdot 17$ & 0.001 & $\begin{array}{c}+3 \cdot 36 \\
(5)\end{array}$ & $5 \cdot 42$ & 0.01 \\
\hline Maltase (mg clucose/ml semen) & $\begin{array}{c}-2 \cdot 33 \\
(9)\end{array}$ & $2 \cdot 81$ & 0.05 & $\begin{array}{c}+0 \cdot 24 \\
(5)\end{array}$ & 0.14 & N.S. \\
\hline Citric acid (mg/ml semen) & $\begin{array}{c}-1 \cdot 45 \\
(8)\end{array}$ & $2 \cdot 56$ & 0.05 & $\begin{array}{r}+0.6 \\
(4)\end{array}$ & $1 \cdot 13$ & N.S. \\
\hline Acid phosphatase ( $\mu \mathrm{mol} / \mathrm{ml}$ semen) & $\begin{array}{c}-5 \cdot 91 \\
(8)\end{array}$ & $1 \cdot 10$ & N.S. & $\begin{array}{r}+3 \cdot 1 \\
(4)\end{array}$ & 0.78 & N.S. \\
\hline
\end{tabular}

* From level before vasectomy: no. of comparisons indicated in parenthesis.

$\dagger$ Paired $t$ test analysis. 
of Midgley (1966), and testosterone by the radioimmunoassay of Castro, Shin \& Chung (1975), seminal maltase activity was estimated according to the method of Rao, Sheth \& Gunaga (1969), fructose by the method of Sheth \& Rao (1959), citric acid by the method of Beutler \& Yeh (1969) and acid phosphatase activity by the method of Bergmeyer (1965). The semen samples were kept on ice after collection and were transferred within $30 \mathrm{~min}$ to the laboratory where they were immediately centrifuged at $1000 \mathrm{~g}$ for $15 \mathrm{~min}$ at $4^{\circ} \mathrm{C}$ to remove the spermatozoa. The supernatants were preserved at $-20^{\circ} \mathrm{C}$ until analyses.

The results are shown in Table 1. No changes in serum testosterone, LH and FSH levels before and after vasectomy were observed. Fructose concentration increased significantly. Maltase activity and citric acid levels had decreased by 3 months after vasectomy but had returned to preoperative levels after 1 year. Seminal acid phosphatase activity showed a similar trend, though the differences were not significant.

Our findings show that vasectomy does not have any effect on circulating levels of testosterone, LH or FSH, although accessory gland function may be affected to some degree.

\section{References}

BERGMEYER, H.V. (1965) Determination in serum with p-nitrophenylphosphate. In Methods of Enzymatic Analysis, pp. 783-785. Eds. Academic Press, New York.

BEUTLER, E. \& YEH, M.K. (1969) Simplified method for the determination of citric acid. J. Lab. clin. Med. $54,125-131$.

Bunge, R.G. (1972) Plasma testosterone levels in man before and after vasectomy. Invest. Urol. 10, 9-11.

Castro, A., Shin, H.H.W. \& Chung, A. (1974) A simple radioimmunoassay of plasma testosterone without column chromatography. Steroids 23, 625-638.

Johnsonbaugh, R.E., O'ConNell, K., Engel, S.B., Edson, M. \& Sode, J. (1975) Plasma testosterone, luteinizing hormone, and follicle-stimulating hormone after vasectomy. Fert. Steril. 26, 329-330.

Kobrinsky, N.L., Winter, J.S.D., Reyes, F.I. \& FAIMAN, C. (1976) Endocrine effects of vasectomy in man. Fert. Steril. 27, 152-156.

Midgley, A.R., JR (1966) Radioimmunoassay: a simplified method for human chorionic gonadotropin and human luteinizing hormone. Endocrino$\log y$ 79, 10-18.

Nun, S., Musacchio, I. \& Epstein, J.A. (1972) Variations in seminal plasma constituents from fertile, subfertile and vasectomized azospermic men. Fert. Steril. 23, 357-360.
Pardanani, D.S., Patil, N.G. \& Powar, H.N. (1976) Some gross observations of the epididymides follow. ing vasectomy: a clinical study. Fert. Steril. 27, 267-270.

RaO, S.S., Sheth, A.R. \& Gunaga, K.P. (1969) Assay of androgenicity of steroids using maltase activity of dorsal prostate of the rat as an index. Indian J. exp. Biol. 7, 20-22.

SHETH, A.R. \& RAO, S.S. (1959) Fructose and fructolysis in human semen determined chromatographically. Experientia 15, 314-315.

Smith, K.D., Tcholankian, R.K., Chowdary, M. \& STEINBERGER, E. (1976) An investigation of plasma hormone levels before and after vasectomy. Fert. Steril. 27, 145-151.

ThakUR, A.N., Sheth, A.R., RAo, S.S. \& Thaker, P.V. (1975) Prostatic function in vasectomized men. Contraception 11, 155-159.

VARMA, M.M., VARMA, R.R., JOHANSON, N.J., KoWARSKI, A. \& MIGeON, C.J. (1975) Long-term effects of vasectomy on pituitary-gonadal function in man. J. clin. Endocr. Metab. 40, 868-871.

Wieland, R.G., HallberG, M.G., Zorn, E.M., Klein, D.E. \& LuRIA, S.S. (1972) Pituitary-gonadal function before and after vasectomy. Fert. Steril. 23, 834 840.

Received 24 June 1976 